\title{
Expression of Tissue Transglutaminase in Human Thyroid Cancer Cell Lines: Effect of Novel Enantiopure Triazole Derivatives
}

Maria A Chiacchio ${ }^{1}$, Roberta Bonfanti ${ }^{1}$, Salvatore V Giofrè ${ }^{2}$, Roberto Romeo ${ }^{2}$, Mariacristina Ferrara ${ }^{1}$, Lorenzo Bandini ${ }^{1}$, Agata Campisi ${ }^{1 *}$ and Ugo Chiacchio ${ }^{1}$

${ }^{1}$ Dipartimento di Scienze del Farmaco, Via A. Doria 6, Catania, Italy

${ }^{2}$ Dipartimento di Scienze del Farmaco e dei prodotti per la salute, Via SS Annunziata, Messina, Italy

\begin{abstract}
A synthesis of (-)5b and (-)6d according to enzymatic resolution of racemic triazole derivatives $5 b$ and $6 d$ was performed with Lipozyme in 1,4-dioxane, using vinyl benzoate as the acyl donor. The effect of the compounds on TG2 overexpression in human thyroid cancer cell lines cultures at two degrees of malignancy and invasiveness was assessed. The involvement of TG2 in the activation of the apoptotic pathway is also shown. We found that the obtained compounds are able to reduce TG2 overexpression in follicular (FTC-133) and anaplastic (8305C) human thyroid cancer cell lines either in the cytosol, or in the nuclear compartment, activating also the apoptotic pathway. Our data suggest that they may represent new anticancer agents for human thyroid cancer.
\end{abstract}

Keywords: Modified nucleosides; Thyroid cancers; Isoxazolidines; Triazole; Antitumor agents; Tissue transglutaminase

\section{Introduction}

TG2 is the ubiquitary and the most abundantly expressed member of the TGs family [1]. It catalyses the formation of protein cross-links, namely $\mathrm{N}^{\varepsilon}$ ( $\gamma$-glutamyl) lysine bridges, between the side chains of peptide-bound Glutamine and Lysine residues [2]. TG2 is a unique member of the TGs family, in that it can also hydrolyse ATP and GTP; when bound to GTP, it functions as a member of the family of GTP-binding proteins [3-6]. TG2 mediates reactions associated with long-term potentiation, synapse formation, tissue differentiation, cell survival [7], apoptosis [8,9], cell adhesion, protein disulfide isomerase [10], kinase [11] and scaffold activities [12]. It is present in the cell, including the extracellular matrix, plasma membrane, cytosol, mitochondria [13] and nucleus [14,15]. The multiple functions of the protein depends on its intracellular localization [16]. In particular, when it is localized in the cytosol differentially controls apoptosis in a stimuli-dependent manner, and its transamidating activity is essential for its pro-apoptotic effects [17,18]. In contrast, when TG2 is localized into the nuclear compartment, it phosphorylates different proteins, including retinoblastoma protein $(\mathrm{Rb})$, a substrate for TG2 kinase activity [19]. Aberrant TG2 expression contributes to a variety of disease processes [20], including cancer [21-25], neurodegenerative diseases [26-31], autoimmune diseases, such as celiac disease [32,33], rheumatoid arthritis [34,35], tissue fibrosis [36].

It has been shown that overexpression of TG2 can lead to an increase of apoptosis, while a decrease in the levels of TG2 involves a decrease both spontaneous apoptosis and inhibits caspase-3 [37,38].

TG2 inhibits its ability to catalyze reactions of protein crosslinking and restores the activation of caspase-3 [39]. Paradoxically, the expression of TG2 can also protect cells from apoptosis [39]. Although some studies have indicated that TG2 may suppress tumor growth and improve the growth inhibitory effects of anti-cancer agents, several studies have presented both roles of survival and anti-apoptotic of TG2 in malignant cells [40].

TG2 represents a single target that can modulate multiple pathways and functions in cancer cells and thus its inhibition can simultaneously deprive cancer cells of multiple pathways that are critical for their growth and survival [41]. Many inhibitors of TG2, including triazole derivatives have been examined [42-48], and a relationship with the development of various types of tumors [49,50], including thyroid cancer has been found. In particular, 1,2,3-triazole motif is exceedingly stable to basic or acidic hydrolysis and interacts strongly with biological targets through hydrogen bonding to nitrogen atoms as well as through dipole-dipole and $\pi$-stacking interactions [51].

On these basis, we have, recently, synthesized a series of 3-hydroxymethyl-5- (1H-1,2,3-triazol) isoxazolidines 5a-f and 6a-f, belonging to the class of $\mathrm{N}, \mathrm{O}$-modified nucleosides [52-59], according to a synthetic approach based on the cycloaddition reaction, under microwave irradiation $(\mathrm{Mw})$, of nitrone1 with 4-substituted 1-vinyl triazoles 2a-f (Scheme 1).

Preliminary biological studies have shown that compounds $5 \mathrm{~b}$ and $6 \mathrm{~d}$ were able to activate the apoptotic pathway in follicular (FTC$133)$ and anaplastic (8305C) human thyroid cancer cell lines, as

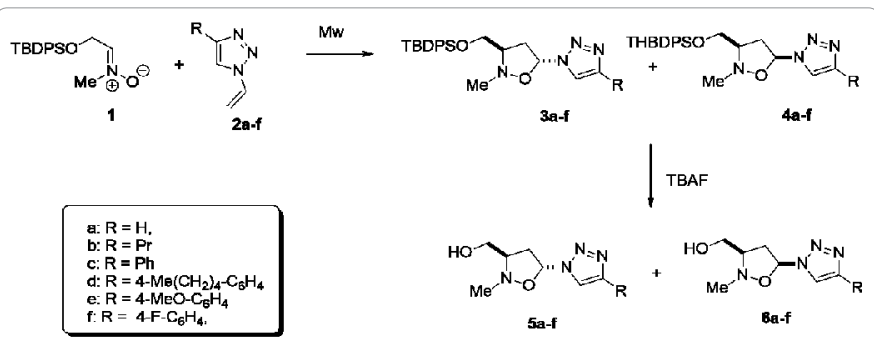

Scheme 1: Synthesis of 3-hydroxymethyl-5- (1H-1,2,3-triazol) isoxazolidines 5a-f and 6a-f.

*Corresponding author: Agata Campisi, Dipartimento di Scienze del Farmaco, Via A. Doria 6, 95125 Catania, Italy, Tel: 00390957384077; Fax: 00390957384220 E-mail: agcampisi@gmail.com

Received July 16, 2015; Accepted September 10, 2015; Published September 14,2015

Citation: Chiacchio MA, Bonfanti R, Giofrè SV, Romeo R, Ferrara M, et al. (2015) Expression of Tissue Transglutaminase in Human Thyroid Cancer Cell Lines: Effect of Novel Enantiopure Triazole Derivatives. Med chem 5: 424-431. doi: 10.4172/2161-0444.1000295

Copyright: ( 2015 Chiacchio MA, et al. This is an open-access article distributed under the terms of the Creative Commons Attribution License, which permits unrestricted use, distribution, and reproduction in any medium, provided the original author and source are credited. 
representative of two aggressive types of human thyroid cancer, poorly differentiated and dedifferentiated, respectively [60].

Herein, we report the enzymatic resolution of triazole derivatives of $(-)-5 b$ and (-)-6d and the effect of (-)-5b and (-)-6d on TG2 overexpression in follicular and anaplastic human thyroid cancer cell line cultures [61,62]. Furthermore, the involvement of TG2 in the activation of the apoptotic pathway is shown.

\section{Experimental Section}

\section{Chemical synthesis}

Solvents and reagents were used as received from commercial sources. Thin layer chromatographic separations were performed on Merck silica gel 60-F254 pre-coated aluminum plates (Merck, Darmstadt, Germany). Flash chromatography was accomplished on Merck silica gel (200-400 mesh). Preparative separations were carried out by a Buchi C-601MPLC (Buchi Italia S.r.l. Milano, Italy), using Merck silica gel $0.040-0.063 \mathrm{~mm}$ and the eluting solvents were delivered by a pump at the low flow rate of 3.0-7.0 $\mathrm{mL} / 7 \mathrm{~min} .{ }^{1} \mathrm{H}-\mathrm{NMR}(500$ $\mathrm{MHz})$ and ${ }^{13} \mathrm{C}-\mathrm{NMR}(125 \mathrm{MHz})$ spectra were recorded in $\mathrm{CDCl}_{3}$, on a Varian 500 instrument (Agilent Technologies, Palo Alto, Ca, USA).

M. miehei (Lipozyme) was purchased from Aldrich. Optical rotations were recorded on a DIP 135 JASCO instrument using a $\phi 5.5$ $\times 100 \mathrm{~mm}$ cell. The enantiomeric excesses and substrate conversions were determined by chiral HPLC analysis using a Chiralcel' OJ (Daicel Chemical Industries) column. C-[(tert-butyldiphenylsilyl)oxy]- $N$ methyl nitrone1, vinyl triazoles $2 \mathrm{~b}, \mathrm{~d}$, and racemic $5 \mathrm{~b}$ and $6 \mathrm{~d}$ were prepared according to the methods described in literature [53].

General procedure for the synthesis of (-)5b and (-)6d: To a solution of racemic substrates $5 \mathrm{~b}$ and $6 \mathrm{~d}(1 \mathrm{mmol})$ in 1,4-dioxane (150 $\mathrm{ml}$ ) was added $2.5 \mathrm{~g}$ of $1 \mathrm{M}$ Lipozyme and vinyl benzoate $(1 \mathrm{mmol})$. The resulting mixture was incubated at $45^{\circ} \mathrm{C}$ and shaken $(300 \mathrm{rpm})$ until $50 \%$ of substrate conversion detected by HPLC analysis. The reaction was stopped and filtered by Celite filter. The resulting solution was evaporated under vacuum, and the residue was purified by MPLC $(\mathrm{CH} 2 \mathrm{Cl} 2 / \mathrm{MeOH}, 98: 2)$ to afford enantiopure (-)5b and (-)6d in 40 and $45 \%$ yield respectively.

((3RS,5RS)-2-methyl-5-(4-propyl-1 H-1,2,3-triazol-1-yl) isoxazolidin-3-yl)methanol (-)5b: Yellow oil: ${ }^{1} \mathrm{H}$ NMR $(500 \mathrm{MHz}$, $\left.\mathrm{CDCl}_{3}\right) \delta: 0.94(3 \mathrm{H}, \mathrm{t}, J=7.1 \mathrm{~Hz}), 1.58-1.73(2 \mathrm{H}, \mathrm{m}), 2.65(2 \mathrm{H}, \mathrm{t}, J=7.5$ $\mathrm{Hz}), 2.80$ (3H, s), 2.81-2.96 (2H, m), 2.97-3.06 (1H, m), $3.75(2 \mathrm{H}, \mathrm{ddd}$, $J=16.3,11.7,3.6 \mathrm{~Hz}), 6.26(1 \mathrm{H}, \mathrm{dd}, J=7.8,2.2 \mathrm{~Hz}), 7.71(1 \mathrm{H}, \mathrm{s}) .{ }^{13} \mathrm{C} \mathrm{NMR}$ $\left(126 \mathrm{MHz}, \mathrm{CDCl}_{3}\right) \delta: 13.9,22.7,27.7,39.0,44.4,61.1,69.0,85.8,119.6$, 148.5. $[\alpha]^{25} \mathrm{D}=-11.2\left(c 08 \mathrm{CH} \mathrm{Cl}_{3}\right)$. Anal. calcd for $\mathrm{C}_{10} \mathrm{H}_{18} \mathrm{~N}_{4} \mathrm{O}_{2}$ : C, 53.08; $\mathrm{H}, 8.02 ; \mathrm{N}, 24.76$; found $\mathrm{C}, 52.89 ; \mathrm{H}, 7.96 ; \mathrm{N}, 24.68$.

((3RS,5SR)-2-methyl-5-(4-(4-pentylphenyl)-1H-1,2,3-triazol-1yl)isoxazolidin-3-yl)methanol(-)6d: White solid, mp: $99-100^{\circ} \mathrm{C} .1 \mathrm{H}$ NMR $\left(500 \mathrm{MHz}, \mathrm{CDCl}_{3}\right) \delta: 0.89(3 \mathrm{H}, \mathrm{t}, \mathrm{J}=6.9 \mathrm{~Hz}), 1.26-1.40(4 \mathrm{H}, \mathrm{m})$, 1.60-1.66 (2H, m), $2.53(2 \mathrm{H}, \mathrm{t}, \mathrm{J}=7.4 \mathrm{~Hz}), 2.76(3 \mathrm{H}, \mathrm{s}), 2.80-2.93(2 \mathrm{H}$, $\mathrm{m}), 3.48-3.58(1 \mathrm{H}, \mathrm{m}), 3.70(2 \mathrm{H}, \mathrm{ddd}, \mathrm{J}=16.5,11.5,4.2 \mathrm{~Hz}), 6.12-6.21$ $(1 \mathrm{H}, \mathrm{m}), 7.24(2 \mathrm{H}, \mathrm{d}, \mathrm{J}=8.0 \mathrm{~Hz}), 7.74(2 \mathrm{H}, \mathrm{d}, \mathrm{J}=8.0 \mathrm{~Hz}), 7.94(1 \mathrm{H}, \mathrm{s})$. 13C NMR (126 MHz, $\left.\mathrm{CDCl}_{3}\right) \delta: 14.1,22.7,31.1,31.6,35.8,36.8,46.7$, $62.1,68.0,88.1,119.2,125.8,127.7,129.1,143.5,148.6 .[\alpha]^{25} \mathrm{D}=-09.6$ (c $04 \mathrm{CHCl}_{3}$ ). Anal. calcd for $\mathrm{C}_{18} \mathrm{H}_{26} \mathrm{~N}_{4} \mathrm{O}_{2}: \mathrm{C}, 65.43 ; \mathrm{H}, 7.93 ; \mathrm{N}, 16.96$; found $\mathrm{C}, 65.41 ; \mathrm{H}, 7.90 ; \mathrm{N}, 16.89$.

The NMR spectra and elemental analysis were identical with the literature data [53].

\section{Cells and reagents}

Human tumor thyroid cell lines: FTC-133 and 8305C, were obtained from Interlab Cell Line Collection (ICLC). Dulbecco's Modified Eagle Medium (DMEM) and Minimum essential Medium (MEM) containing 2 mM Gluta-MAX (GIBCO), Ham's F12 (GIBCO), non-essential amino acids, heat inactivated- Foetal Bovine Serum (FBS, GIBCO), Normal Goat Serum (NGS, GIBCO), Streptomycin and penicillin antibiotics, Trypsin-EDTA $0.05 \%$ solution, and Mouse anti-Human Transferrin Receptor (TfR-1) monoclonal antibody were obtained from Invitrogen (Milano, Italia). Lab-Tek ${ }^{\text {Tw }}$ Chamber Slides II, 3(4,5-dimethyl-thiazol-2-yl)2,5-diphenyl-tetrazolium bromide salts (MTT), and other chemicals (DMSO, Tris- $\mathrm{HCl}, \mathrm{NaCl}$, PMSF and Tween 20) of analytical grade were obtained from SigmaAldrich (Milano, Italy) and microplate spectrophotometer reader (Titertek Multiskan; Flow Laboratories, Helsinki, Finland) to measure the optical density of each well, 3-hydroxymethyl-5- (1H-1,2,3triazol) isoxazolidines 5b and 6d [53]. Mouse monoclonal antibody against TG2 was from NeoMarkers (Bioptica, Milan, Italy). Mouse monoclonal antibody against caspase-3 was from Becton Dickinson (Milan, Italy). Mouse monoclonal antibody against $\beta$-tubulin and tetrarhodamine isothiocyanate (TRITC)-conjugated anti-mouse IgG were from Chemicon (Prodotti Gianni, Milan, Italy). ApoAlert DNA fragmentation assay kit was from Clontech (Milan, Italy). Developing system for immunoblots was from Super Signal West Pico Chemiluminescent Substrate was from Thermo Scientific (Milan, Italy).

\section{Cell cultures}

FTC-133 and $8305 \mathrm{C}$ cell lines were suspended in appropriate medium and plated in flasks at a final density of $2 \times 10^{6}$ cells or in Lab-Tek $^{\text {tu }}$ Chamber Slides II at a final density $0.5 \times 10^{5}$ cells/ well. Specifically the medium for FTC-133 cell lines was: DMEM containing $2 \mathrm{mM}$ Gluta-MAX, 10\% FBS, streptomycin $(50 \mu \mathrm{g} / \mathrm{mL})$, penicillin $(50 \mathrm{U} / \mathrm{mL})$; whereas, the medium for $8305 \mathrm{C}$ cell lines was: MEM containing $2 \mathrm{mM}$ Gluta-MAX, 10\% FBS, streptomycin $(50 \mu \mathrm{g} / \mathrm{mL})$, penicillin $(50 \mathrm{U} / \mathrm{mL})$, and $1 \%$ Non-Essential Amino Acids. Cell lines were then incubated at $37^{\circ} \mathrm{C}$ in humidified atmosphere containing $5 \%$ $\mathrm{CO}_{2}$ and the medium was replaced every 2 or 3 days. When the cultures were about $85-90 \%$ confluent, cells were trypsinized by $0.05 \%$ trypsin and $0.53 \mathrm{mM}$ EDTA at $37^{\circ} \mathrm{C}$ in humidified atmosphere containing $5 \% \mathrm{CO}_{2}$ for $5 \mathrm{~min}$. Trypsinization was stopped by adding 20\% FBS, resuspended and plated in flasks fed with fresh basic complete media. Cells were seeded again at $1: 4$ density ratio and incubated at $37^{\circ} \mathrm{C}$ in humidified atmosphere containing $5 \% \mathrm{CO}_{2}$.

\section{Treatment of cell cultures}

FTC-133 and 8305C cell line cultures were replicated on to Lab$\mathrm{Tek}^{\mathrm{Tw}}$ Chamber Slides II at a final density of $1 \times 10^{4}$ cells/well, or in 75 $\mathrm{cm}^{2}$ flasks at a final density of $1 \times 10^{5}$ cells $/ \mathrm{mL}$ and fed in fresh complete medium. In preliminary experiments, a lot of the both cell cultures were exposed to different concentrations of synthesized triazole derivatives $(-) 5 \mathrm{~b}$ and $(-) 6 \mathrm{~d}[53](0.5,1,5,10,25,50,100 \mu \mathrm{M})$ for $12,24,48 \mathrm{hr}$, in order to establish the optimal concentrations and their exposure times to the triazole derivates $[28,62,63]$. For this purpose, MTT test and morphological characterization were utilized [30].

\section{MTT bioassay}

Cell survival analysis was performed by MTT reduction assay, evaluating mitochondrial dehydrogenase activity $[28,30]$. The test was conducted according to the method described by Mosmann (1983). Cells were set up $6 \times 10^{5}$ cells per well of a 96-multiwell, flat-bottomed, 
$200 \mu \mathrm{L}$ microplate, and maintained at $37^{\circ} \mathrm{C}$ in a humidified $5 \%$ $\mathrm{CO} 2 / 95 \%$ air mixture. At the end of treatment time $20 \mu \mathrm{L}$ of $0.5 \%$ MTT in (pH 7.4) PBS were added to each microwell. After $1 \mathrm{hr}$ of incubation with the reagent, the supernatant was removed and replaced with 200 $\mu \mathrm{L}$ of dimethyl sulfoxide (DMSO).

The optical density of each well was measured with a microplate spectrophotometer reader (Titertek Multiskan; Flow Laboratories, Helsinki, Finland) at $\lambda 570 \mathrm{~nm}$. Since all the compounds were dissolved in DMSO, some cultures were treated with the same concentration of DMSO. No significant changes in cellular viability in DMSOtreated FTC-133 and $8305 \mathrm{C}$ cancer cell line cultures was found, when compared with the respective untreated control. Thus, the effect of drug- treatment of cancer cell line cultures was compared with that DMSO-treated alone, and it was used as control.

\section{Immunocytochemistry}

Expression and localization of TG2 and caspase- 3 in untreated and $5 \mu \mathrm{M}$ triazole derivatives treated FTC-133 and 8305C culture cell lines was identified by immunocytochemical procedures [14,28,30,31].

The cells were fixed by exposing to $4 \%$ paraformaldehyde in $0.1 \mathrm{M}$ PBS for $30 \mathrm{~min}$. The cells were successively incubated overnight in the primary antibodies: anti-TG2 monoclonal antibody (1:500) or mouse anti-caspase-3 monoclonal antibody (1:500). Then, coverslips were incubated with a secondary antibodies, TRITC-conjugated anti-mouse IgG anti-mouse antibody (1:200). Coverslips were washed, mounted in PBS/glycerol (50:50), placed on glass microscope slides and analysed on a fluorescent microscopy (Leica, Germany). No non-specific staining of FTC-133 and 8305C was observed in control incubations in which the primary antibody was omitted.

\section{TUNEL test}

The ApoAlert DNA fragmentation assay kit detecting nuclear DNA fragmentation kit, a hallmark of apoptosis, was used. The ApoAlert DNA fragmentation assay incorporates fluorescein-dUTP at the free 3'-hydroxyl ends of the fragmented DNA using TUNEL and was performed according to the user's manual. FTC-133 and 8305C cell cultures, untreated and treated for $24 \mathrm{~h}$ with $5 \mu \mathrm{M}$ of Gemcitabine, or (-)5b or (-)6d compounds were made up according to the user's manual. Cells were mounted and visualized directly by fluorescence microscopy (Leika, Germany) with either a propidium iodide (PI) filter alone or a FITC filter alone. According to the user's manual, apoptotic cells appear green with the FITC filter alone while non apoptotic cells appear red under the dual- pass FITC/PI filter set. We focused on 10 random microscopic fields for each dish. In each microscopic field we counted the number of apoptotic cells and we compared this number with all the non-apoptotic cells visualized in the same microscopic field.

\section{Statistical analysis}

Data were statistically analysed using one-way analysis of variance (one-way ANOVA) followed by post hoc Holm-Sidak test to estimate significant differences among groups. Data were reported as mean of four experiments in duplicate, and differences between groups were considered to be significant at ${ }^{*} p<0.05$.

\section{Results and Discussion}

\section{Chemistry}

The racemic triazoles (+/-) 5b and (+/-)6d, obtained by 1,3-dipolar cycloaddition reaction of $C$ - [(tert-butyldiphenylsilyl)oxy]- $N$-methyl nitrone 1 with vinyl triazoles $2 \mathrm{~b}, \mathrm{~d}$, followed by TBAF treatment, were converted into the enantiomeric pure (-)5b and (-)6d by an esterification reaction, catalyzed by Lipozyme $1 \mathrm{M}$ in 1,4-dioxane, using vinyl benzoate as the acyl donor (Scheme 2).

The esterification reaction was monitored by HPLC chiral analysis and stopped after 50\% of conversion. The reaction mixture was chromatographed on silica gel eluting with $\mathrm{CH}_{2} \mathrm{Cl}_{2} / \mathrm{MeOH}$ 98:2 to afford the benzoate derivatives $7 \mathrm{~b}$ and $7 \mathrm{~d}$ as mixture of enantiomers, and (-)5b, and (-)6d in enantiomeric pure forms. The absolute configuration reported as $(3 R, 5 R)$ - for $5 b$ and $(3 R, 5 S)$ - for $6 d$, see experimental section, is arbitrary and can be inverted. The benzoate derivatives $7 \mathrm{~b}$ and $7 \mathrm{~d}$ were, then, dissolved in 1,4-dioxane and the alcoholysis using $n$-butanol in the presence of Lypozyme $1 \mathrm{M}$ was attempted. Unfortunately, this reaction occurred very slowly giving a negligible amount of $(+) 5 \mathrm{~b}$ and $(+) 6 \mathrm{~d}$; thus further efforts to obtain these enantiomers in good yields were abandoned.

\section{Cytotoxic effect of (-)5b and (-)6d}

In preliminary experiments, some cultures of both cell lines were treated with different concentrations of (-)5b and (-)6d (1, 5, 10, 20, 40, 80 and $100 \mu \mathrm{M})$ for $24 \mathrm{hr}$, to perform the MTT test. It was found that the compounds were able to reduce the cell viability at concentration of $5 \mu \mathrm{M}$ for $24 \mathrm{hr}$. The cytotoxic effect appeared more evident in FTC-133 cell lines (Figure 1).

The $50 \%$ cytotoxic inhibitory concentration $\left(\mathrm{IC}_{50}\right)$, causing $50 \%$ decreasing in cell proliferations, obtained graphically from doseeffect curves using Prism 5.0 (GraphPad Software Inc.). In particular, compound (-)5b has shown an $\mathrm{IC}_{50}$ for FTC-133=4.1 $\mu \mathrm{M}$ and $=7.6 \mu \mathrm{M}$ for $8305 \mathrm{C}$, while compound (-)6d has shown an $\mathrm{IC}_{50}$ for $\mathrm{FTC}-133=3.9$ $\mu \mathrm{M}$ and $=7.9 \mu \mathrm{M}$ for $8305 \mathrm{C}$. The effect was compared with Gemcitabine

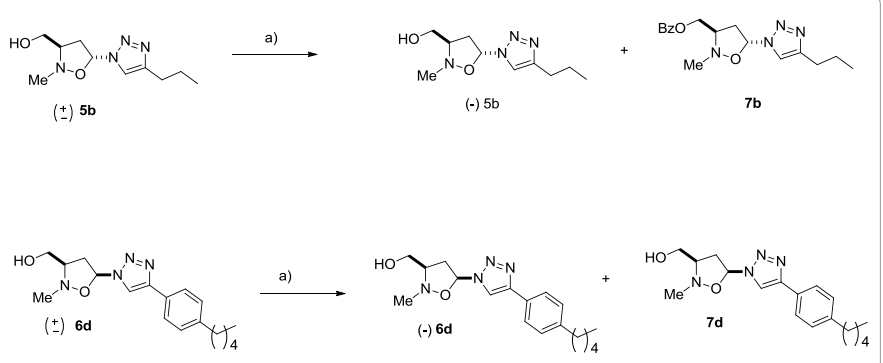

Scheme 2: Enzymatic formation of (-)5b and (-)6d. Reagents and conditions: (a) Lipozyme, 1,4- dioxane, vinyl benzoate, $45^{\circ} \mathrm{C}$.

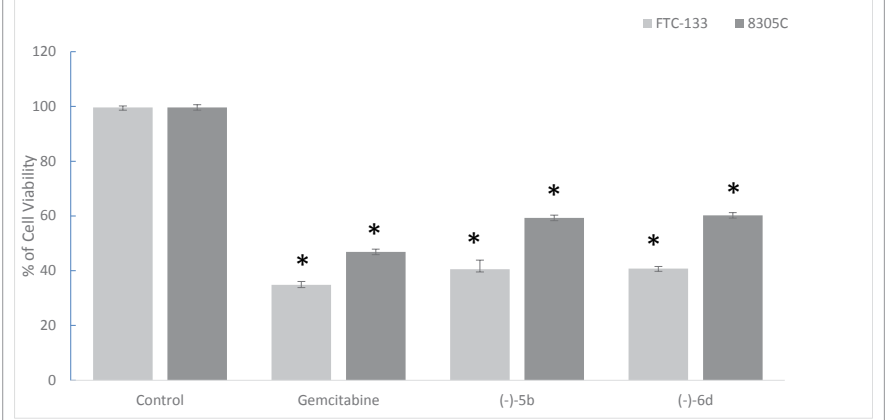

Figure 1: Cell viability by MTT assay in FTC-133 and $8305 \mathrm{C}$ human thyroid cancer cell lines untreated (Control) or DMSO without drugs (Control drugs) or treated with $5 \mu \mathrm{M}(-) 5 \mathrm{~b}$, (-)6d triazole derivatives and Gemcitabine for $24 \mathrm{hr}$. The values represent the mean \pm S.D. of 4 experiments performed in duplicate. *Significance to the control: $p<0.001$. 
used as reference compound $\left(\mathrm{IC}_{50}\right.$; FTC-133 $=3.2 \mu \mathrm{M}$ and $8305 \mathrm{C}=4.8$ $\mu \mathrm{M})$ [64].

\section{Effect of (-)5b and (-)6d on TG2}

Figures 2 and 3 show the expression of TG2 in FTC-133 human thyroid cancer cell lines untreated or treated with $5 \mu \mathrm{M}(-) 5 \mathrm{~b}$, (-)6d triazole derivatives and Gemcitabine for $24 \mathrm{hr}$ evaluated by immunocytochemical techniques on single cell and by Western Blot analysis on total cell lysates. Immunocytochemical analysis for the positivity of untreated-cells, used as a control, TG2 showed a high levels of the protein in the both cell lines. The protein appeared prevalently localized in the both cell lines the cytosol and also in the nuclear compartment. The treatment of the cells with (-)5b and (-)6d or Gemcitabine induced a dramatic reduction of the protein levels. The quantification and statistical analysis of TG2 immunolabeling obtained and collected from 4 fields/coverslip of four separate experiments. No non-specific staining of cells was observed in control incubations in which the primary antibody was omitted.

TG2 into the nuclear compartment, which is related to the increase of intracellular $\mathrm{Ca}^{2+}$ concentration. Nuclear TG2 plays an important role in the regulation gene expression via post- translational modification of (or interaction with) transcriptional factors and related proteins [11,19].

Through this mechanism, TG2 controls cell growth or survival, differentiation and apoptosis, and is involved in the pathogenesis and/or treatment of cancers. The balance between import from the cytoplasm to the nucleus, and export from the nucleus to the cytoplasm, determines the level of TG2 in the nucleus [31].

Figures 4 and 5 report a representative immunoblot and densitometric analysis of TG2 expression in FTC-133 and 8305C performed by Western blotting experiments on total cellular lysates.

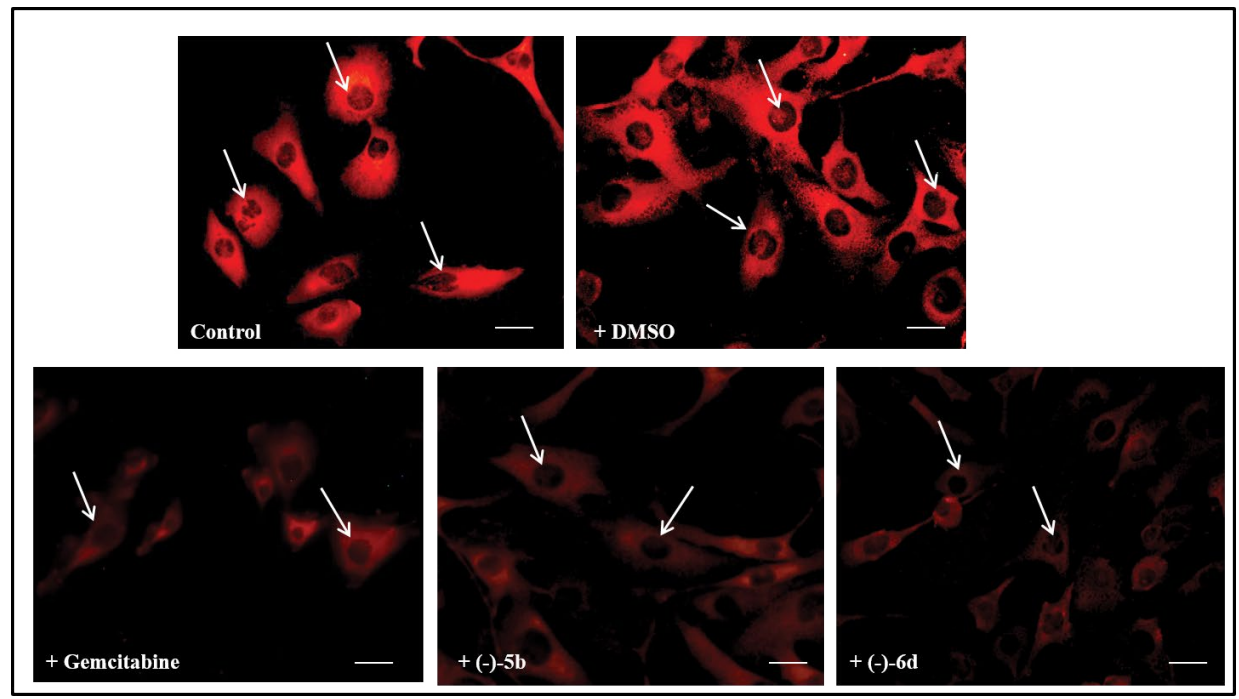

Figure 2: Fluorescent microscopic analysis of TG2 expression in FTC-133 human thyroid cancer cell lines untreated (Control) or DMSO without drugs (Control drugs) or treated with $5 \mu \mathrm{M}(-) 5 \mathrm{~b},(-) 6 \mathrm{~d}$ triazole derivatives and Gemcitabine for $24 \mathrm{hr}$. Magnification is equal in all pictures. Scale bars $=50 \mu \mathrm{m}$.

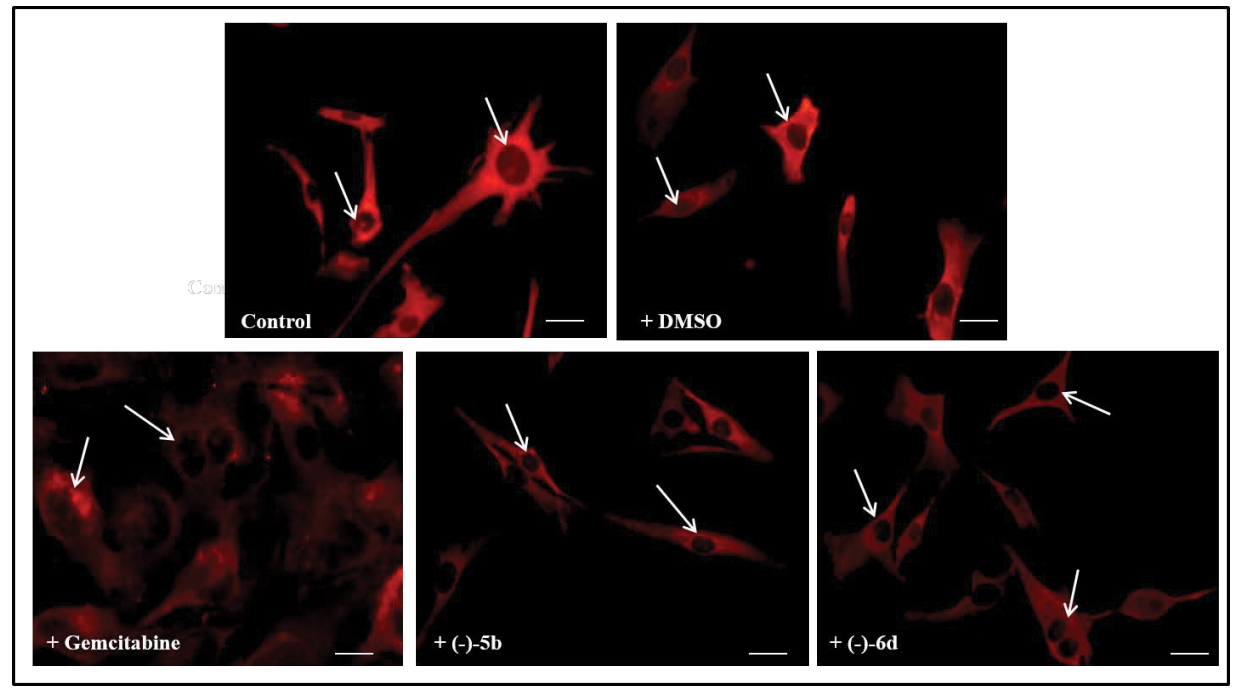

Figure 3: Fluorescent microscopic analysis of TG2 expression in $8305 \mathrm{C}$ human thyroid cancer cell lines untreated (Control) or DMSO without drugs

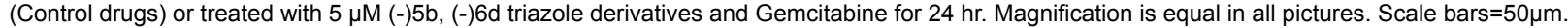


A)

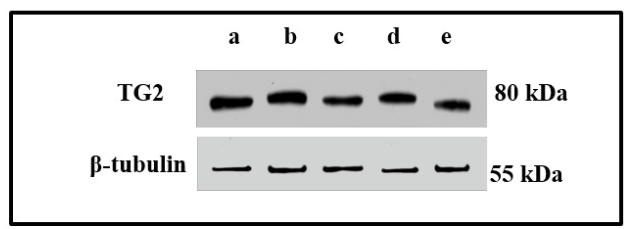

B)

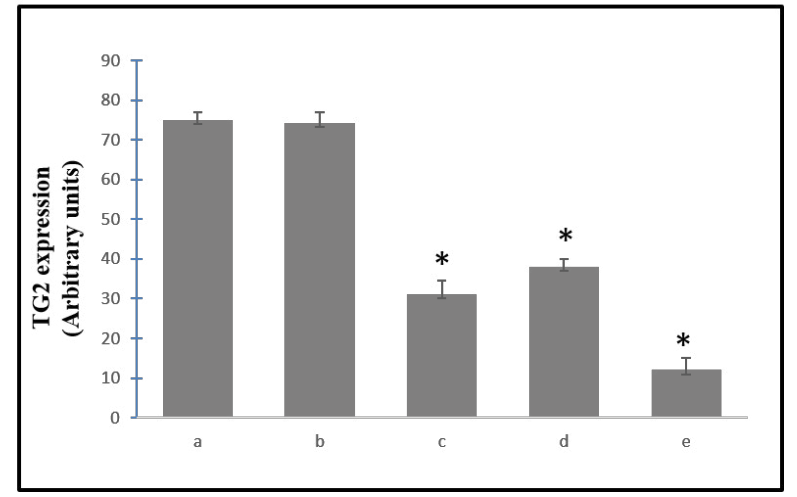

Figure 4: A) Representative immunoblots of TG2 expression in FTC-133 human thyroid cancer cell lines (a) untreated (Control) or DMSO without drugs (Control drugs) or treated with $5 \mu \mathrm{M}$ (b) (-)5b, (c) (-)6d triazole derivatives and (e) Gemcitabine for $24 \mathrm{hr}$. (B) Densitometric analysis of TG2 expression (performed after normalization with $\beta$-Tubulin) in response to drugs treatment, when compared with ones untreated used as control. Blots shown are representative of Western blot analysis of four experiments in duplicate. Results are expressed as the mean \pm S.D. of the values of four experiments in duplicate. ${ }^{*} p<0.05$, significant differences vs controls.
A)

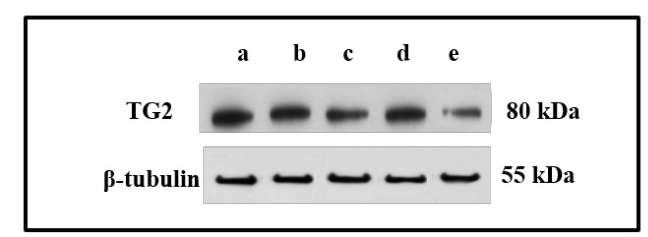

B)

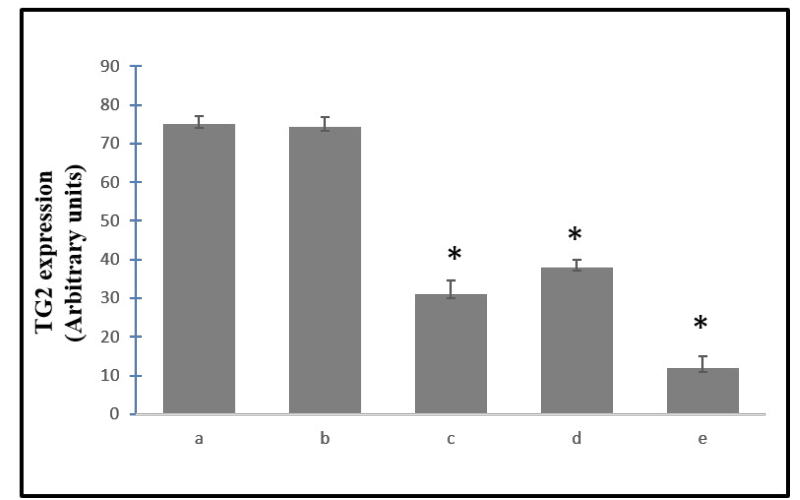

Figure 5: A) Representative immunoblots of TG2 expression in 8305C human thyroid cancer cell lines (a) untreated (Control) or DMSO without drugs (Control drugs) or treated with $5 \mu \mathrm{M}$ (b) (-)5b, (c) (-)6d triazole derivatives and (e) Gemcitabine for $24 \mathrm{hr}$. (B) Densitometric analysis of TG2 expression (performed after normalization with $\beta$-tubulin) in response to drugs treatment, when compared with ones untreated used as control. Blots shown are representative of Western blot analysis of four experiments in duplicate. Results are expressed as the mean \pm SD of the values of four experiments in duplicate. ${ }^{*} p<0.05$, significant differences $v s$ controls.

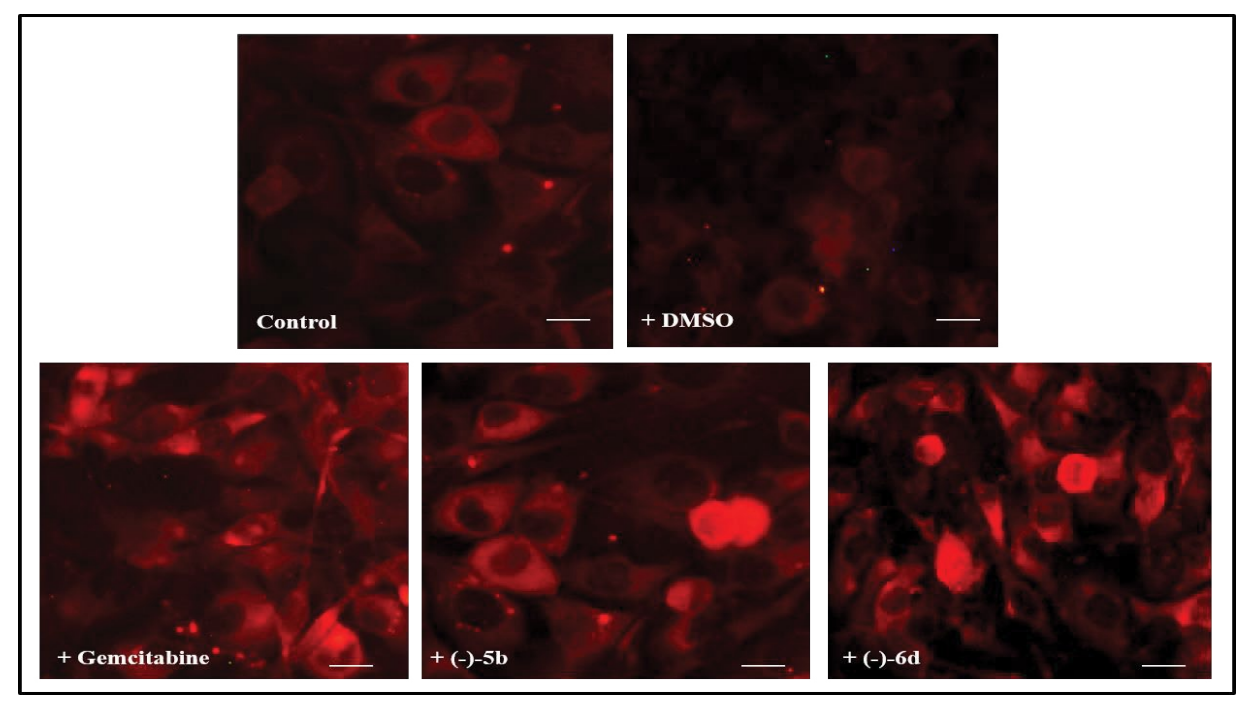

Figure 6: Fluorescent microscopic analysis of caspase-3 cleavage in FTC-133 human thyroid cancer cell lines untreated (Control) or DMSO without drugs (Control drugs) or treated with $5 \mu \mathrm{M}(-) 5 \mathrm{~b},(-) 6 \mathrm{~d}$ triazole derivatives and Gemcitabine for $24 \mathrm{hr}$. Magnification is equal in all pictures. Scale bars $=50 \mu \mathrm{m}$.

An overexpression of TG2 was observed untreated FTC-133 and 8305C human thyroid cancer cell lines. The treatment of the cells with $(-) 5 \mathrm{~b}$ and (-)6d or Gemcitabine induced a dramatic reduction of the protein levels. FTC-133 cells were more susceptible to treatment with the synthesized derivatives, than the $8305 \mathrm{C}$ cell lines.

\section{Effect of (-)5b and (-)6d on DNA fragmentation in thyroid cancer cell lines}

To assess if the triazole compounds were able to activate the apoptotic pathway and involvement of TG2 in its activation, we evaluated caspase-3 cleavage and DNA fragmentation by TUNEL 


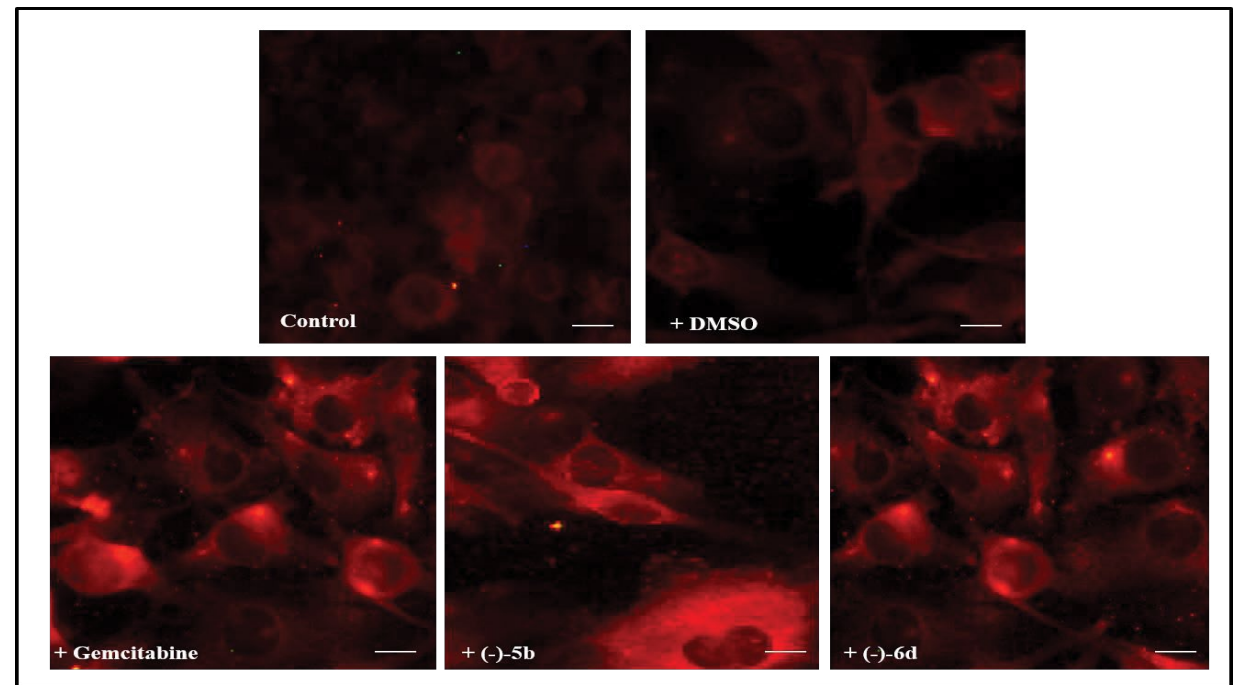

Figure 7: Fluorescent microscopic analysis of caspase-3 cleavage in 8305C human thyroid cancer cell lines untreated (Control) or DMSO without drugs (Control drugs) or treated with $5 \mu \mathrm{M}(-) 5 \mathrm{~b},(-) 6 \mathrm{~d}$ triazole derivatives and Gemcitabine for $24 \mathrm{hr}$. Magnification is equal in all pictures. Scale bars $=50 \mu \mathrm{m}$.

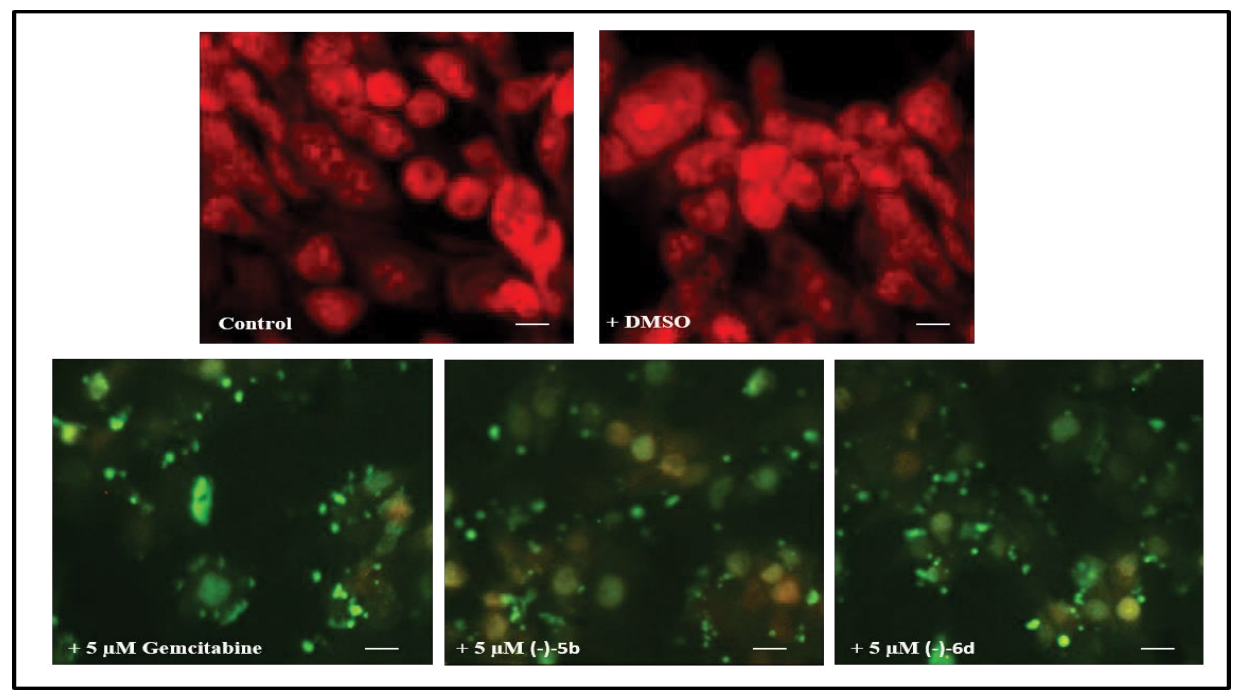

Figure 8: Representative pictures of TUNEL assay performed in FTC-133 human thyroid cancer cell lines unexposed (Control) or DMSO without drugs (Control drugs) and exposed to $5 \mu \mathrm{M}(-) 5 \mathrm{~b}$, (-)6d triazole derivatives and Gemcitabine for $24 \mathrm{hr}$. Immunostaining of non-apoptotic (red) and apoptotic (green) cells is shown. Magnification is equal in all pictures. Scale bars $=50 \mu \mathrm{m}$.

test. Figures 6 and 7 show caspase-3 cleavage performed by immunocytochemical procedures in FTC-

133 and $8305 \mathrm{C}$ cancer cell lines in absence or in presence of Gemcitabine or (-)5b or (-)-6d. A significant number of positive cells to caspase- 3 in the both cell lines exposed to drugs was found. The percentage of positive cells was higher in cell cultures of follicular thyroid cancer, when compared with the anaplastic cancer cell lines.

The ability of (-)5b or (-)6d compounds to activate the apoptotic pathway by measuring DNA fragmentation by TUNEL test (terminal deoxynucleotidyl-transferase mediated dUTP nick-end- labeling test) was also assessed. The effect was also compared with Gemcitabine. This set of experiments showed a significant increase of DNA fragmentation in FTC-133 and $8305 \mathrm{C}$ cells treated with all the compounds, when compared with the respective controls. The effect appeared more evident in FTC-133 cancer cell lines (Figures 8 and 9). The obtained data show that the triazole derivatives induced DNA fragmentation depending on the degree of tumor invasiveness.

\section{Conclusions}

In summary, we report an efficient synthesis of (-)5b and (-)6d according to enzymatic resolution of racemic triazole derivatives $5 \mathrm{~b}$ and $6 \mathrm{~d}$ performed with Lipozyme $1 \mathrm{M}$ in 1,4-dioxane, using vinyl benzoate as the acyl donor. Biological tests indicate that the obtained compounds are able to reduce TG2 overexpression in follicular and anaplastic human thyroid cancer cell lines either in the cytosol, or in 


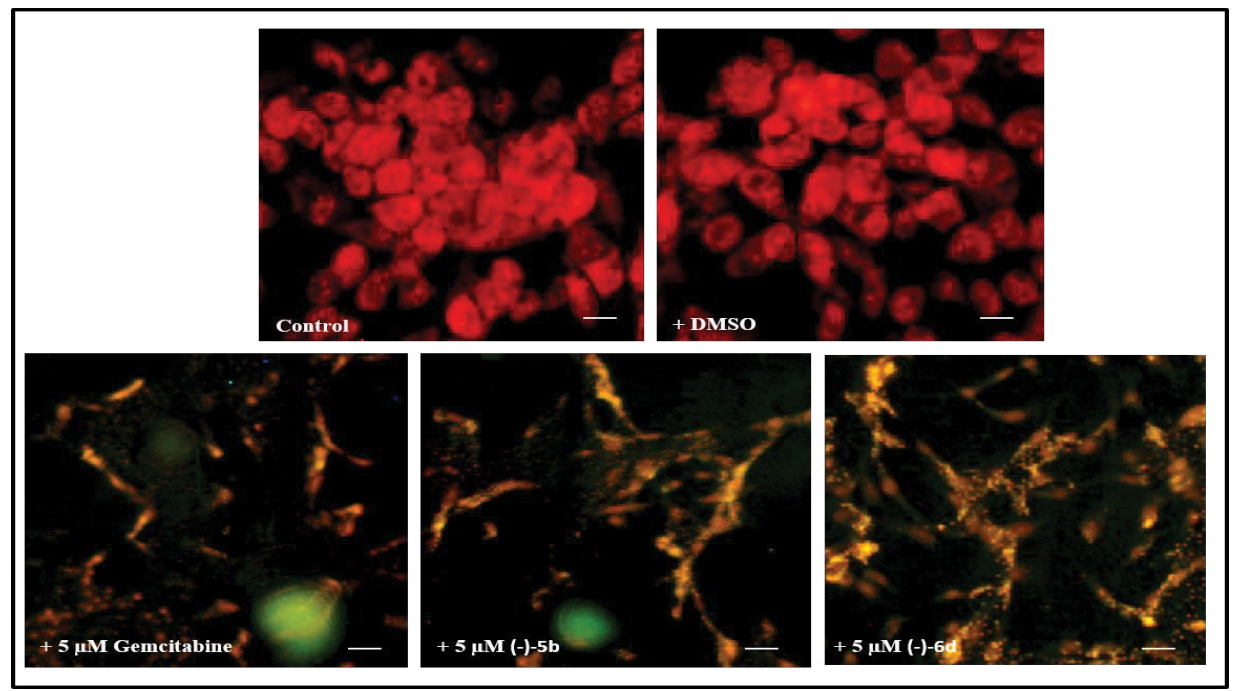

Figure 9: Representative pictures of TUNEL assay performed in $8305 \mathrm{C}$ human thyroid cancer cell lines unexposed (Control) or DMSO without drugs (Control drugs) and exposed to $5 \mu \mathrm{M}$ (-)5b, (-)6d triazole derivatives and Gemcitabine for $24 \mathrm{hr}$. Immunostaining of non-apoptotic (red) and apoptotic (green) cells is shown. Magnification is equal in all pictures. Scale bars $=50 \mu \mathrm{m}$.

the nuclear compartment, activating also the apoptotic pathway and suggest that they may represent new potential anticancer agents.

\section{Acknowledgments}

The authors gratefully acknowledge the Italian Ministry of Education, Universities, and Research (MIUR), FIR of the University of Catania (Italy) and the University of Messina (Italy) and CINMPIS (Interuniversity Consortium for Innovative Methodologies and Processes for Synthesis) for partial financial support.

\section{References}

1. Fesus L, Piacentini M (2002) Transglutaminase 2: an enigmatic enzyme with diverse functions. Trends Biochem Sci 27: 534-539.

2. Lorand L, Graham RM (2003) Transglutaminases: crosslinking enzymes with pleiotropic functions. Nat Rev Mol Cell Biol 4: 140-156.

3. Folk JE (1980) Transglutaminases. Annu Rev Biochem 49: 517-531.

4. Grenard P, Bates MK, Aeschlimann D (2001) Evolution of transglutaminase genes: identification of a transglutaminase gene cluster on human chromosome $15 q 15$. Structure of the gene encoding transglutaminase $X$ and a novel gene family member, transglutaminase Z. J Biol Chem 276: 33066-33078.

5. Stamnaes J, Fleckenstein B, Sollid LM (2008) The propensity for deamidation and transamidation of peptides by transglutaminase 2 is dependent on substrate affinity and reaction conditions. Biochim Biophys Acta 1784: 1804-1811.

6. Kumar A, Xu J, Sung B, Kumar S, Yu D, et al. (2012) Evidence that GTPbinding domain but not catalytic domain of transglutaminase 2 is essential for epithelial-to-mesenchymal transition in mammary epithelial cells. Breast Cancer Res 14: R4.

7. Antonyak MA, Singh US, Lee DA, Boehm JE, Combs C, et al. (2001) Effects of tissue transglutaminase on retinoic acid-induced cellular differentiation and protection against apoptosis. J Biol Chem 276: 33582-33587.

8. Piacentini M, Fesus L, Farrace MG, Ghibelli L, Piredda L, et al. (1991) The expression of "tissue" transglutaminase in two human cancer cell lines is related with the programmed cell death (apoptosis). Eur J Cell Biol 54: 246-254.

9. Nicholas B, Smethurst P, Verderio E, Jones RA, Griffin M (2003) Cross-linking of cellular proteins by tissue transglutaminase during necrotic cell death: a mechanism for maintaining tissue integrity. Biochem J 371: 413-422.

10. Hasegawa G, Suwa M, Ichikawa Y, Ohtsuka T, Kumagai S, et al. (2003) A novel function of tissue-type transglutaminase: protein disulphide isomerase. Biochem J 373: 793-803.

11. Mishra S, Murphy LJ (2004) Tissue transglutaminase has intrinsic kinase activity: identification of transglutaminase 2 as an insulin-like growth factorbinding protein-3 kinase. J Biol Chem 279: 23863-23868.

12. Nakaoka H, Perez DM, Baek KJ, Das T, Husain A, et al. (1994) Gh: a GTPbinding protein with transglutaminase activity and receptor signaling function. Sci 264: 1593-1596.

13. Piacentini M, Farrace MG, Piredda L, Matarrese P, Ciccosanti F, et al. (2002) Transglutaminase overexpression sensitizes neuronal cell lines to apoptosis by increasing mitochondrial membrane potential and cellular oxidative stress. $J$ Neurochem 81: 1061-1072.

14. Campisi A, Caccamo D, Raciti G, CannavÃ $\tilde{A}^{2}$ G, Macaione V, et al. (2003) Glutamate-induced increases in transglutaminase activity in primary cultures of astroglial cells. Brain Res 978: 24-30.

15. Milakovic T, Tucholski J, McCoy E, Johnson GV (2004) Intracellular localization and activity state of tissue transglutaminase differentially impacts cell death. $J$ Biol Chem 279: 8715-8722.

16. Kuo TF, Tatsukawa $H$, Kojima $S$ (2011) New insights into the functions and localization of nuclear transglutaminase 2. FEBS J 278: 4756-4767.

17. Fesus L, Szondy $Z$ (2005) Transglutaminase 2 in the balance of cell death and survival. FEBS Lett 579: 3297-3302.

18. Boroughs LK, Antonyak MA, Cerione RA (2014) A novel mechanism by which tissue transglutaminase activates signaling events that promote cell survival. J Biol Chem 289: 10115-10125.

19. Mishra S, Melino G, Murphy LJ (2007) Transglutaminase 2 kinase activity facilitates protein kinase A-induced phosphorylation of retinoblastoma protein. J Biol Chem 282: 18108-18115

20. Facchiano F, Facchiano A, Facchiano AM (2006) The role of transglutaminase-2 and its substrates in human diseases. Front Biosci 11: 1758-1773.

21. Mehta K, Fok J, Miller FR, Koul D, Sahin AA (2004) Prognostic significance of tissue transglutaminase in drug resistant and metastatic breast cancer. Clin Cancer Res 10: 8068-8076.

22. Mangala LS, Mehta K (2005) Tissue transglutaminase (TG2) in cancer biology. Prog Exp Tumor Res 38: 125-138.

23. Agnihotri N, Kumar S, Mehta K (2013) Tissue transglutaminase as a centra mediator in inflammation-induced progression of breast cancer. Breast Cance Res 15: 202.

24. Assi J, Srivastava G, Matta A, Chang MC, Walfish PG, et al. (2013) Transglutaminase 2 overexpression in tumor stroma identifies invasive ductal carcinomas of breast at high risk of recurrence. PLoS One 8: e74437. 
25. Fisher ML, Adhikary G, Xu W, Kerr C, Keillor JW, et al. (2015) Type II transglutaminase stimulates epidermal cancer stem cell epithelial-mesenchymal transition. Oncotarget 6: 20525-20539.

26. Lesort M, Tucholski J, Miller ML, Johnson GV (2000) Tissue transglutaminase: a possible role in neurodegenerative diseases. Prog Neurobiol 61: 439-463.

27. Kim SY, Jeitner TM, Steinert PM (2002) Transglutaminases in disease. Neurochem Int 40: 85-103.

28. Campisi A, Caccamo D, Li Volti G, Currò M, Parisi G, et al. (2004) Glutamateevoked redox state alterations are involved in tissue transglutaminase upregulation in primary astrocyte cultures. FEBS Lett 578: 80-84.

29. Campisi A, Bramanti V, Caccamo D, Li Volti G, Cannavo G, et al. (2008) Effect of growth factors and steroids on transglutaminase activity and expression in primary astroglial cell cultures. J Neurosci Res 86: 1297-1305.

30. Campisi A, Spatuzza M, Russo A, Raciti G, Vanella A, et al. (2012) Expression of tissue transglutaminase on primary olfactory ensheathing cells cultures exposed to stress conditions. Neurosci Res 72: 289-295.

31. Vanella L, Raciti G, Barbagallo I, Bonfanti R, Abraham N, et al. (2015) Tissue transglutaminase expression during neural differentiation of human mesenchymal stem cells. CNS Neurol Disord Drug Targets 14: 24-32.

32. Dieterich W, Ehnis T, Bauer M, Donner P, Volta U, et al. (1997) Identification of tissue transglutaminase as the autoantigen of celiac disease. Nat Med 3 . 797-801.

33. Paolella G, Caputo I, Marabotti A, Lepretti M, Salzano AM, et al. (2013) Celiac anti-type 2 transglutaminase antibodies induce phosphoproteome modification in intestinal epithelial Caco-2 cells. PLoS One 8: e84403.

34. Johnson K, Hashimoto S, Lotz M, Pritzker K, Terkeltaub R (2001) Interleukin-1 induces pro-mineralizing activity of cartilage tissue transglutaminase and factor XIIla. Am J Pathol 159: 149-163.

35. Lauzier A, Charbonneau M, Paquette M, Harper K, Dubois CM (2012) Transglutaminase 2 cross-linking activity is linked to invadopodia formation and cartilage breakdown in arthritis. Arthritis Res Ther 14: R159.

36. Griffin M, Casadio R, Bergamini CM (2002) Transglutaminases: nature's biological glues. Biochem J 368: 377-396.

37. Melino G, Piacentini M (1998) 'Tissue' transglutaminase in cell death: a downstream or a multifunctional upstream effector? FEBS Lett 430: 59-63.

38. Fesus L (1998) Transglutaminase-catalyzed protein cross-linking in the molecular program of apoptosis and its relationship to neuronal processes. Cell Mol Neurobiol 18: 683-694.

39. Chhabra A, Verma A, Mehta K (2009) Tissue transglutaminase promotes or suppresses tumors depending on cell context. Anticancer Res 29: 1909-1919.

40. Budillon A, Carbone C, Di Gennaro E (2013) Tissue transglutaminase: a new target to reverse cancer drug resistance. Amino Acids 44: 63-72.

41. Mehta K, Kumar A, Kim HI (2010) Transglutaminase 2: a multi-tasking protein in the complex circuitry of inflammation and cancer. Biochem Pharmacol 80: 1921-1929.

42. Pardin C, Roy I, Lubell WD, Keillor JW (2008) Reversible and competitive cinnamoyl triazole inhibitors of tissue transglutaminase. Chem Biol Drug Des 72: $189-196$

43. Pardin C, Pelletier JN, Lubell WD, Keillor JW (2008) Cinnamoyl inhibitors of tissue transglutaminase. J Org Chem 73: 5766-5775.

44. Duval E, Case A, Stein RL, Cuny GD (2005) Structure-activity relationship study of novel tissue transglutaminase inhibitors. Bioorg Med Chem Lett 15 1885-1889.

45. Griffin M, Mongeot A, Collighan R, Saint RE, Jones RA, et al. (2008) Synthesis of potent water-soluble tissue transglutaminase inhibitors. Bioorg Med Chem Lett 18: 5559-5562.

46. Badarau E, Collighan RJ, Griffin M (2013) Recent advances in the development of tissue transglutaminase (TG2) inhibitors. Amino Acids 44: 119-127.

47. Kim N, Kwak SH, Lee SH, Juvekar V, Lee BI, et al. (2014) Novel 3-arylethynylsubstituted thieno[3,4-b]pyrazine derivatives as human transglutaminase 2 inhibitors. Org Biomol Chem 12: 4932-4940.
48. Keillor JW, Apperley KY, Akbar A (2015) Inhibitors of tissue transglutaminase. Trends Pharmacol Sci 36: 32-40.

49. Verma A, Wang H, Manavathi B, Fok JY, Mann AP, et al. (2006) Increased expression of tissue transglutaminase in pancreatic ductal adenocarcinoma and its implications in drug resistance and metastasis. Cancer Res 66: 1052510533.

50. Palmieri G, Montella L, Aiello C, Barbieri F, Di Vizio D, et al. (2007) Somatostatin analogues, a series of tissue transglutaminase inducers, as a new tool for therapy of mesenchimal tumors of the gastrointestinal tract. Amino Acids 32 $395-400$.

51. Najera C, Sansano JM (2009) 1,3-Dipolar cycloadditions: applications to the synthesis of antiviral agents. Org Biomol Chem 7: 4567-4581.

52. Piperno A, Giofre SV, lannazzo D, Romeo R, Romeo G, et al. (2010) Synthesis of C-4'truncated phosphonated carbocyclic 2'-oxa-3'-azanucleosides as antiviral agents. J Org Chem 75: 2798-2805.

53. Romeo R, Giofre SV, Garozzo A, Bisignano B, Corsaro A, et al. (2013) Synthesis and biological evaluation of furopyrimidine N,O-nucleosides. Bioorg Med Chem 21: 5688-5693.

54. Romeo R, Giofre SV, Carnovale C, Campisi A, Parenti R, et al. (2013) Synthesis and biological evaluation of 3-hydroxymethyl-5-(1H-,2,3-triazol) isoxazolidines. Bioorg Med Chem 21: 7929-7937.

55. Romeo R, Navarra M, Giofre SV, Carnovale C, Cirmi S, et al. (2014) Synthesis and biological activity of new arenediyne-linked isoxazolidines. Bioorg Med Chem 22: 3379-3385.

56. Romeo R, Giofre SV, Carnovale C, Chiacchio MA, Campisi A, et al. (2014) Synthesis and Biological Activity of Triazole-Appended N,O-Nucleosides. Eur J Org Chem 25: 5442-5447.

57. Giofre SV, Romeo R, Chiacchio U, Romeo G, Chiacchio MA (2015) Phosphonated N,O-Nucleosides: Synthesis and Biological Evaluation. MiniRev Org Chem 12: 249-257.

58. Giofre SV, Romeo R, Carnovale C, Mancuso R, Cirmi S, et al. (2015) Synthesis and biological properties of 5-(1H-,2,3-triazol-4-yl)isoxazolidines: a new class of C-nucleosides. Molecules 20: 5260-5275.

59. Romeo R, Carnovale C, Giofre SV, Chiacchio MA, Garozzo A, et al. (2015) C-5'-Triazolyl-2'-oxa-3'-aza-4'a-carbanucleosides: Synthesis and biological evaluation. Beilstein J Org Chem 11: 328-334.

60. Pellegriti G, De Vathaire F, Scollo C, Attard M, Giordano C, et al. (2009) Papillary thyroid cancer incidence in the volcanic area of Sicily. J Natl Cancer Inst 101: 1575-1583.

61. Malandrino P, Pellegriti G, Attard M, Violi MA, Giordano C, et al. (2013) Papillary thyroid microcarcinomas: a comparative study of the characteristics and risk factors at presentation in two cancer registries. J Clin Endocrinol Metab 98: 1427-1434.

62. an Staveren WC, Solis DW, Delys L, Duprez L, Andry G, et al. (2007) Human thyroid tumor cell lines derived from different tumor types present a common dedifferentiated phenotype. Cancer Res 17: 8113-8120.

63. Wunderlich A, Fischer M, Schlosshauer T, Ramaswamy A, Greene BH, et al. (2011) Evaluation of Aurora kinase inhibition as a new therapeutic strategy in anaplastic and poorly differentiated follicular thyroid cancer. Cancer Sci 102 762-768.

64. Gesto DS, Cerqueira NM, Fernandes PA, Ramos MJ (2012) Gemcitabine: a critical nucleoside for cancer therapy. Curr Med Chem 19: 1076-1087. 